\title{
Brazilian regional differences and factors associated with the prevalence of cesarean sections
}

\author{
Diferenças regionais brasileiras e fatores \\ associados à prevalência de cesárea
}

Diferencias regionales brasileñas y factores
asociados a la prevalencia de parto cesárea

Laiane Santos Eufrásio ${ }^{[a]}$, Damião Ernane de Souza ${ }^{[b]}$, Aline Medeiros Cavalcanti da Fonsêca ${ }^{[c]}$, Elizabel de Souza Ramalho Viana ${ }^{[]^{*}}$

[a] Universidade Federal do Piauí (UFPI), Parnaíba, PI, Brazil

[b] Instituto Brasileiro de Geografia e Estatística (IBGE), Natal, RN, Brazil

[c] Universidade Federal do Rio Grande do Norte (UFRN), Natal, RN, Brazil

\section{Abstract}

Introduction: Brazil presents high C-section prevalence rates. Several factors may be associated with such high rates. Objective: To observe and analyze factors associated with the prevalence of cesarean sections in Brazil, according to their occurrence in Brazilian regions. Methods: An ecological study, having C-section as the outcome, from 1990 to 2013, in Brazilian regions, using data from the Brazilian National Health Survey, 2013. Records of women in their reproductive period, aged between 18 and 49 years, were included, totaling a sample of 16,175 women. Descriptive and bivariate analysis was carried out with logistic regression. Results: The prevalence of cesarean sections in Brazil

*LSE: PhD, e-mail: laieufrasio@hotmail.com

DES: PhD, e-mail: souzade73@gmail.com

AMCF: PhD, e-mail: alinemeca@gmail.com

ESRV: PhD, e-mail: elizabelviana@gmail.com 
was 53.03\%. Vaginal delivery was more prevalent in the North (52.74\%) and Northeast (51.06\%) regions, while C-section was more prevalent in the Southeast (59.32\%), South (56.96\%) and Midwest (61.48\%) regions. Over the years, an increased probability of cesarean sections was observed, particularly in the following regions: Northeast (2.21 times more, CI95\%: 1,42 - 3,46) and South (2.75 times more, CI95\%: 1,44 - 5,23). Women with higher levels of education are 2.05 times (CI95\%: 1.27 - 3.30) more likely to have a C-section, especially those in the Northern and Southern regions. In the Northeast, this probability increased, regardless of the level of education. Conclusion: The prevalence of cesarean sections in Brazil is high and, over the years, factors such as level of education, maternal age and having health insurance, seem to contribute to the increase in surgical deliveries.

Keywords: Women's Health. Cesarean Section. Prevalence. Brazil.

\section{Resumo}

Introdução: O Brasil apresenta altos níveis de prevalência de partos cesáreas. Vários fatores podem estar associados a essas taxas elevadas. Objetivo: Observar e analisar fatores associados à prevalência de cesáreas no Brasil, de acordo com a ocorrência nas regiões brasileiras. Métodos: Estudo ecológico, cujo desfecho é o parto cesáreo, na série histórica de 1990 a 2013, no contexto das regiões brasileiras, com dados da Pesquisa Nacional de Saúde, 2013. Foram incluídos registros de mulheres em período reprodutivo, com idade entre 18 e 49 anos, totalizando 16.175 mulheres na amostra. Foi realizada a análise descritiva e bivariada, com a regressão logística. Resultados: A prevalência de partos cesarianos no Brasil foi de 53,03\%. O parto vaginal foi mais prevalente nas regiões Norte (52,74\%) e Nordeste (51,06\%), enquanto o parto cesáreo nas regiões Sudeste (59,32\%), Sul (56,96\%) e Centro Oeste (61,48\%). Com o passar dos anos, foi evidenciado um aumento na probabilidade de ter parto cesárea, principalmente nas regiões Nordeste (2,21 vezes mais, IC95: 1.42 - 3.46) e Sul (2,75 vezes mais, IC95: 1.44 - 5.23). Mulheres com maiores níveis de escolaridade têm 2,05 vezes (IC95\%: 1.27 - 3.30) mais chances de ter um parto cesárea, com destaque as das regiões Norte e Sul. No Nordeste, esta probabilidade aumentou, independentemente do nível de escolaridade. Conclusão: A prevalência de cesáreas no Brasil é alta e, com o passar dos anos, fatores como grau de escolaridade, idade materna e ter plano de saúde parecem contribuir para o aumento dos partos cirúrgicos.

Palavras-chave: Saúde da Mulher. Cesárea. Prevalência. Brasil.

\section{Resumen}

Introducción: Brasil presenta altos niveles de prevalencia de partos cesáreas. Varios factores pueden estar asociados a estas altas tasas. Objetivo: Observar y analizar factores asociados a la prevalencia de cesáreas en Brasil, de acuerdo con la ocurrencia en las regiones brasileñas. Métodos: Estudio ecológico, cuyo desenlace es el parto cesáreo, en la serie histórica de 1990 a 2013, en el contexto de las regiones brasileñas, con datos de la Encuesta Nacional de Salud, 2013. Se incluyeron registros de mujeres en período reproductivo, con edad entre 18 y 49 años, totalizando 16.175 mujeres en la muestra. Se realizó el análisis descriptivo y bivariado, con la regresión logística. Resultados: La prevalencia de partos cesarianos en Brasil fue del 53,03\%. El parto vaginal fue más prevalente en las regiones Norte (52,74\%) y Nordeste (51,06\%), mientras que el parto cesáreo en las regiones Sudeste (59,32\%), Sur (56,96\%) y Centro Oeste (61,48\%). Con el paso de los años, se evidenció un aumento en la probabilidad de tener parto cesárea, principalmente en las regiones: Nordeste (2,21 veces más, IC95: 1.42 - 3.46) y Sur (2,75 veces más, IC95: 1.44 - 5.23). Las mujeres con mayores niveles de escolaridad tienen 2,05 veces (IC95\%: 1.27 - 3.30) más posibilidades de tener un parto cesáreo, con destaque las de las regiones Norte y Sur. En el Nordeste, esta probabilidad aumentó, independientemente del nivel de escolaridad. Conclusión: La prevalencia de cesáreas en Brasil es alta y, con el paso de los años, factores como grado de escolaridad, edad materna y tener plan de salud, parecen contribuir al aumento de los partos quirúrgicos.

Palabras clave: Salud de la Mujer. Cesárea. Prevalencia. Brasil. 


\section{Introduction}

Cesarean section ( $\mathrm{C}$-section) is a surgical intervention, originally developed to save the life of the mother and the fetus, during pregnancy and labor, and provides security to the pregnant woman and her baby, in more complex situations [1, 2]. The real indications for C-sections are described by Mylonas and Friese [3], and among which we have as absolute indications: cephalopelvic disproportion, chorioamnionitis (intra-amniotic infection), deformity of maternal pelvic bones, eclampsia, intrauterine hypoxia or fetal acidosis, umbilical cord prolapse, placenta previa, abnormal fetal presentation, and uterine rupture. Pathological cardiotocography, failure of labor progress and previous $\mathrm{C}$-section are among the related indications.

C-section, if correctly indicated, is effective in reducing maternal and perinatal mortality. However, it has been carried out indiscriminately in most of the world $[1,4]$. Since 1985, the international medical community considers the 10\%-15\%-rate of C-sections ideal for any region of the world. Yet, a continuous increase can be observed in this rate in recent decades, both in developed and developing countries [5].

The determinants for the increase in trend of C-sections are still not well defined. Some authors mention that this increase is due to the large number of C-sections carried out without medical indication, exposing both mother and baby to unnecessary risks, such as infections, injuries to organs, thromboembolic complications, among others. Such risks may be greater in women who have limited access to adequate obstetric care, and continue for many years after delivery, compromising the health of the binomial mother-baby, in addition to the fact that this may also affect future gestations $[4,6,7]$.

According to Rocha and Silva [8] and Dias et al. [9], quality prenatal care and birth assistance, associated with a multidisciplinary approach, would ensure lower rates of C-sections, as well as reduce maternal and fetal risks, maternal mortality and public expenditures with hospitalizations. Thus, the importance of attention to the pregnant woman is highlighted, as governmental policy, inserted in the set of standards which rule the Unified Health System (SUS - Sistema Único de Saúde).

In Brazil, since 1984, women's healthcare has been on the rise with the creation of the PAISM - Programa de Atenção Integral de Saúde da Mulher (Women's Integral Health Care Program), PHPN - Programa de Humanização no Pré-natal e Nascimento (Prenatal and Birth Humanization Program) in 2000, PNAISM Política Nacional de Atenção Integral à Saúde da Mulher
(National Policy for Women's Integral Health Care), in 2004, and Rede Cegonha (Stork Network) in 2011 [10]. Such public policies have developed over the years, and have been increasingly seeking new possibilities and rights for women. However, due to the heterogeneity that characterizes our country, both in relation to socioeconomic and cultural conditions, and in access to these actions and health services, the female population presents different epidemiological profiles from one region to another within the country [11].

Some studies show that the South, Southeast and Midwest regions are more urban regions, with richer States, higher number of inhabitants and births, while the North and Northeast regions are more rural and poorer [12]. Thus, with the increase in C-section rates in Brazil, predominantly observed since 1970, and considering the characteristics of each region, the importance of identifying and studying factors associated with the choice of type of delivery is emphasized. In this context, the aim of this study is that interventions and public policies are also oriented towards such factors contributing to improve the quality of care provided to women during their puerperal pregnancy cycle. In addition, it aims to promote empowerment and incentive to the active participation in gestation, birth and postpartum periods, always aligned with birth humanization principles. Therefore, the study objective was to analyze the factors associated with the prevalence of C-sections in Brazilian regions.

\section{Methods}

An ecological study, having C-section as the outcome, from 1990 to 2013, in Brazilian regions, using data from the Brazilian National Health Survey (PNS - Pesquisa Nacional de Saúde), carried out in 2013 by the Brazilian Institute of Geography and Statistics (IBGE - Instituto Brasileiro de Geografia e Estatística) in partnership with the Ministry of Health. The PNS was approved by the National Health Council (CNS - Conselho Nacional de Saúde) and its National Committee for Ethics in Research (CONEP - Comissão Nacional de Ética em Pesquisa), under № 328.159, of June 26, 2013. All participants signed an Informed Consent Form, ensuring data confidentiality. The sample represents permanent residents, located in urban or rural zones of five major geographical regions, 27 states, capitals and other cities. The PNS sample selection was carried out in three steps: 1 - selection of census sectors; 2 - selection 
of households; and 3 - selection of individuals aged 18 or above. All data was collected by trained interviewers, through handheld computers (Personal Digital Assistance - PDA). The questionnaire used in the PNS comprised three parts: 1 - with household variables, 2 - with variables of all household members and 3 individual, with questions targeting an adult resident (aged 18 or above), randomly selected [13].

Thepopulation of women who participated in the PNSwas 106,310, and for sample selection in this study an approach was determined and data from those who responded to the individual questionnaire was included, totaling 16,175 records of women in reproductive period, aged between 18 and 49 years. Proxy questions for this study were: "Haveyou ever been pregnant?","How many births have you had?" and "How many C-sections have you had?"

The outcome variable - C-section - was assessed through self-report of participants, as described and documented in the PNS. Independent variables included socio-demographic data, lifestyle, chronic diseases, health conditions, gynecological and obstetric data, in addition to the time factor (in years).

The sample studied was obtained according to the flowchart below (Figure 1).

\section{Results}

STATA ${ }^{\circledR}$ software version 9 (StatCorp, College Station, Texas, EUA) was used to perform the statistical analysis. The characterization of the sample was made by means of absolute frequency (n) and relative frequency (percentage) of the analyzed variables. As a method of inferential statistics, bivariate analysis was performed to verify the associations described, represented in odds ratio (OR) and 95\% confidence interval (CI95\%) through logistic regression.

A total of 16,175 women, in reproductive period, were evaluated with average age of $35.16( \pm 8.00)$ years. Of these, $65.47 \%$ declared themselves as mixed race, black or other races. According to the level of education, $51.51 \%$ of the women had finished elementary school and most women in the sample $(92.70 \%)$ had some kind of paid work at the time of the survey.

As for the perception of their health condition and chronic diseases, $69.09 \%$ reported their general health as good, $12.88 \%$ reported having high blood pressure, $2.68 \%$ reported diabetes and $16.33 \%$ reported chronic back problem.

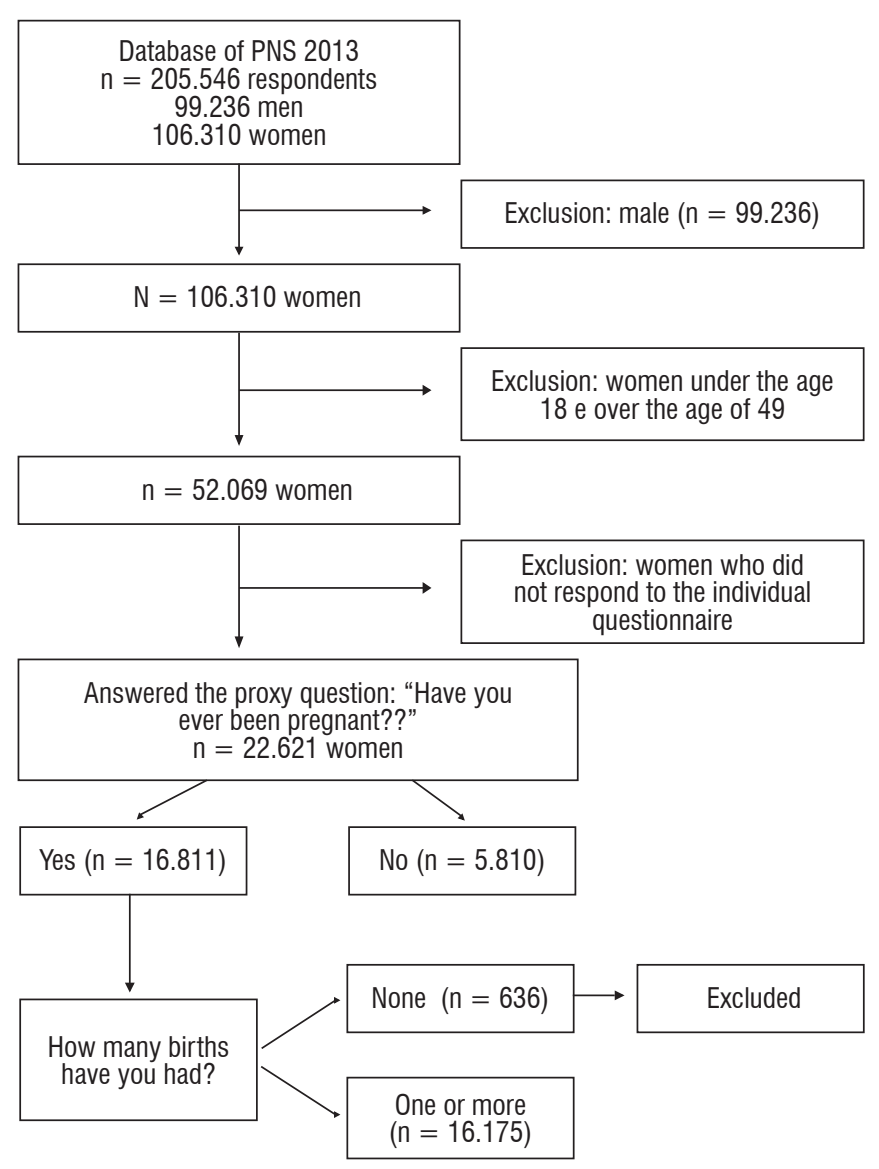

Figure 1 - Flowchart. 
Taking into consideration the gynecological and obstetric history of the sample, the average age of first pregnancy among the women interviewed was $20.65( \pm 5.1)$ years. The average births in the sample was 2.36 ( \pm 1.5 ), and $53.03 \%$ reported having had, at least, one $\mathrm{C}$-section.

Socio-demographic variables, lifestyle, health and gynecological and obstetric conditions of the sample are shown in relative frequency and absolute frequency for better visualization of the sample characterization (Table 1 ).

Table 1 - Sociodemographic, lifestyle, health conditions and gynecological and obstetrical characteristics of the total sample ( $n=16.175$, Brazil, 2013)

\begin{tabular}{|c|c|c|}
\hline \multirow[b]{2}{*}{ Variables } & \multicolumn{2}{|c|}{ Total $\mathrm{n}=16.175$} \\
\hline & $\begin{array}{c}\text { Absolute } \\
\text { frequency }(\mathrm{n})\end{array}$ & $\begin{array}{c}\text { Relative } \\
\text { frequency (\%) }\end{array}$ \\
\hline \multicolumn{3}{|l|}{ Race } \\
\hline White & 5.586 & 34.53 \\
\hline Black, brown and other & 10.589 & 65.47 \\
\hline \multicolumn{3}{|l|}{$\begin{array}{l}\text { Marital status - Lives with } \\
\text { partner }\end{array}$} \\
\hline Yes & 11.313 & 69.94 \\
\hline No & 4.862 & 30.06 \\
\hline \multicolumn{3}{|l|}{ Schooling } \\
\hline Finished elementary school & 8.334 & 51.52 \\
\hline High school or more & 7.841 & 48.48 \\
\hline \multicolumn{3}{|l|}{ Ocupation } \\
\hline Yes & 9.444 & 92.70 \\
\hline No & 744 & 7.30 \\
\hline \multicolumn{3}{|l|}{ Smoker } \\
\hline Yes & 1.838 & 11.36 \\
\hline No & 14.337 & 88.64 \\
\hline \multicolumn{3}{|l|}{ Alcoholic } \\
\hline Yes & 4.885 & 30.20 \\
\hline No & 11.290 & 69.80 \\
\hline \multicolumn{3}{|l|}{ Physical activity (3 months) } \\
\hline Yes & 3.692 & 22.83 \\
\hline No & 12.483 & 77.17 \\
\hline \multicolumn{3}{|l|}{ Self-reported health } \\
\hline Good & 11.175 & 69.09 \\
\hline Precarious & 5.000 & 30.91 \\
\hline \multicolumn{3}{|l|}{ Diagnosis of hypertension } \\
\hline Yes & 2.084 & 12.88 \\
\hline No & 14.091 & 87.12 \\
\hline \multicolumn{3}{|l|}{ Diagnosis of Diabetes } \\
\hline Yes & 433 & 2.68 \\
\hline No & 15.742 & 97.32 \\
\hline \multicolumn{3}{|l|}{ Chronic back problem } \\
\hline Yes & 2.642 & 16.33 \\
\hline No & 13.533 & 83.67 \\
\hline \multicolumn{3}{|l|}{ Has health plan } \\
\hline Yes & 3.686 & 22.79 \\
\hline No & 12.489 & 77.21 \\
\hline
\end{tabular}

\begin{tabular}{llc}
\hline \multirow{2}{*}{ Variables } & \multicolumn{2}{c}{ Total $\mathbf{n}=\mathbf{1 6 . 1 7 5}$} \\
\cline { 2 - 3 } & $\begin{array}{c}\text { Absolute } \\
\text { frequency }(\mathrm{n})\end{array}$ & $\begin{array}{c}\text { Relative } \\
\text { frequency }(\%)\end{array}$ \\
\hline $\begin{array}{l}\text { Age of menarche } \\
\quad<12 \text { years }\end{array}$ & 2.911 & 18.00 \\
$\quad \geq 12$ years & 13.264 & 82.00 \\
$\begin{array}{l}\text { Cesarean section } \\
\quad \text { None }\end{array}$ & 7.597 & 46.97 \\
$\quad$ One or more & 8.578 & 53.03 \\
$\quad$ Children of low weight & & \\
$\quad$ None & 13.846 & 85.60 \\
$\quad$ One or more & 2.329 & 14.40 \\
Pre-term children & & \\
$\quad$ None & 13.691 & 84.64 \\
$\quad$ One or more & 2.484 & 15.36 \\
Pregnant at time of research & & \\
$\quad$ Yes & 506 & 3.13 \\
$\quad$ No & 15.669 & 96.87 \\
\hline
\end{tabular}

The prevalence of women who had C-sections in Brazil was $53.03 \%$. Associating the variable type of delivery (vaginal or C-section) and including Brazilian regions, we observe that there is statistically significant difference ( $p=0.000)$, being vaginal delivery the most prevalent in the North $(52.74 \%)$ and Northeast $(51.06 \%)$ regions, while $\mathrm{C}$-sections are more prevalent in the Southeast (59.32\%), South (56.96\%) and Midwest $(61.48 \%)$ regions. The percentages of the two types of childbirth in Brazil by region are shown in Figure 2.

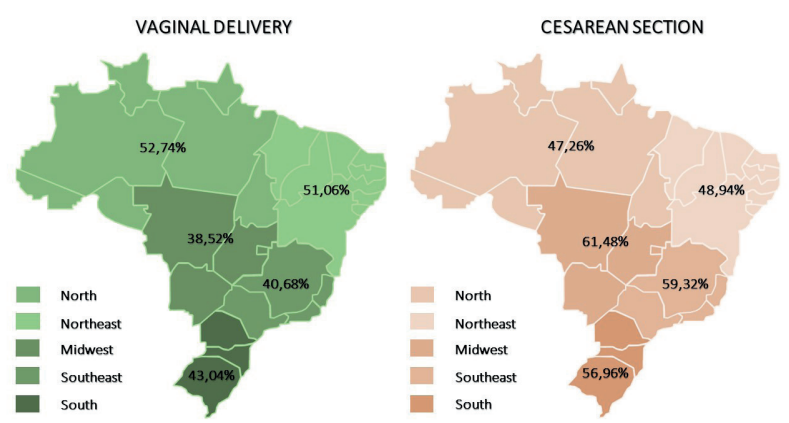

Figure 2 - Relative frequency according to the type of childbirth in the Brazilian regions ( $n=16.175$, Brazil, 2013). Source: PNS, 2013.

According to the logistic regression, performed to analyze some of the factors associated with C-sections, an increase in the likelihood of having C-sections in the temporal factor (Table 2), over the years, was observed mainly in the following regions: Northeast (121\%, CI95: 1.42-3.46) and South (175\%, CI95: $1.44-5.23)$. 
Table 2 - Association of cesarean section over the years in Brazilian regions ( $\mathrm{n}=16.175$, Brazil, 2013)

\begin{tabular}{|c|c|c|}
\hline Variables & $\begin{array}{l}\text { Odds } \\
\text { Ratio }\end{array}$ & $\begin{array}{l}\text { Confidence } \\
\text { Interval } 95 \%\end{array}$ \\
\hline $\begin{array}{l}\text { NORTH } \\
\text { Year of the last childbirth } \\
\quad \geq 1990 \text { and } \leq 2000 \\
>2000 \text { and } \leq 2010 \\
>2010\end{array}$ & $\begin{array}{l}1.12 \\
.93 \\
.97\end{array}$ & $\begin{array}{l}.636-1.99 \\
.533-1.62 \\
.554-1.72\end{array}$ \\
\hline $\begin{array}{l}\text { NORTHEAST } \\
\text { Year of the last childbirth } \\
\quad \geq 1990 \text { and } \leq 2000 \\
>2000 \text { and } \leq 2010 \\
>2010\end{array}$ & $\begin{array}{l}1.42 \\
1.70 \\
2.21\end{array}$ & $\begin{array}{l}.919-2.20 \\
1.134-2.57 \text { * } \\
1.422-3.46 \text { * }\end{array}$ \\
\hline $\begin{array}{l}\text { SOUTHEAST } \\
\text { Year of the last childbirth } \\
\qquad 1990 \text { and } \leq 2000 \\
>2000 \text { and } \leq 2010 \\
>2010\end{array}$ & $\begin{array}{l}1.32 \\
1.40 \\
1.56\end{array}$ & $\begin{array}{l}.824-2.13 \\
.899-2.20 \\
.933-2.61\end{array}$ \\
\hline $\begin{array}{l}\text { SOUTH } \\
\text { Year of the last childbirth } \\
\qquad \begin{aligned} \geq 1990 \text { and } \leq 2000 \\
>2000 \text { and } \leq 2010 \\
>2010\end{aligned}\end{array}$ & $\begin{array}{l}1.16 \\
1.70 \\
2.75\end{array}$ & $\begin{array}{l}.648-2.08 \\
.946-3.07 \\
1.446-5.23^{\star}\end{array}$ \\
\hline $\begin{array}{l}\text { MIDWEST } \\
\text { Year of the last childbirth } \\
\quad \geq 1990 \text { and } \leq 2000 \\
>2000 \text { and } \leq 2010 \\
>2010\end{array}$ & $\begin{array}{l}.800 \\
.981 \\
.993\end{array}$ & $\begin{array}{l}.503-1.27 \\
.619-1.55 \\
.613-1.61\end{array}$ \\
\hline
\end{tabular}

Note: * Statistical significance.

The level of education variable showed association with the type of delivery. The study observed that, for higher levels of education of the total Brazilian sample, over time (from 1990 to 2013) the chance of having a C-section increased by 2.05 times (CI95\%: 1.27-3.30). This finding was seen for all Brazilian regions, especially in the North, NortheastandSouth, wherethechances ofaC-section in women with ahigher level of education were quite significant over the years (Table 3).

Table 3 - Association of cesarean section and level of education over the years in Brazilian regions ( $n=16.175$, Brazil, 2013)

\begin{tabular}{lllll}
\hline \multicolumn{1}{c}{ Variables } & \multicolumn{2}{c}{$\begin{array}{c}\text { Lower level of } \\
\text { education }\end{array}$} & \multicolumn{2}{c}{$\begin{array}{c}\text { Higher level of } \\
\text { education }\end{array}$} \\
\cline { 2 - 6 } & $\mathrm{OR}$ & $\mathrm{Cl} 95 \%$ & $\mathrm{OR}$ & $\mathrm{Cl} 95 \%$ \\
\hline NORTH & & & & \\
Year of the last childbirth: & & & & \\
$\geq 1990$ and $\leq 2000$ & .75 & $.35-1.63$ & 2.33 & $1.07-5.07^{\star}$ \\
$>2000$ and $\leq 2010$ & .52 & $.25-1.09$ & 2.28 & $1.07-4.88^{*}$ \\
$\quad>2010$ & .53 & $.25-1.13$ & 2.51 & $1.12-5.64^{*}$ \\
\hline
\end{tabular}

\begin{tabular}{ccccc}
\hline \multirow{2}{*}{ Variables } & \multicolumn{2}{c}{$\begin{array}{c}\text { Lower level of } \\
\text { education }\end{array}$} & \multicolumn{2}{c}{$\begin{array}{c}\text { Higher level of } \\
\text { education }\end{array}$} \\
\cline { 2 - 5 } & OR & Cl 95\% & OR & Cl 95\% \\
\hline NORTHEAST & & & & \\
Year of the last childbirth: & & & & \\
$\geq 1990$ and $\leq 2000$ & 1.61 & $.99-2.63$ & 1.11 & $.54-2.30$ \\
$>2000$ and $\leq 2010$ & 1.80 & $1.17-2.78^{*}$ & 1.30 & $.63-2.71$ \\
$>2010$ & 1.75 & $1.07-2.86^{*}$ & 2.42 & $1.15-5.12^{*}$ \\
SOUTHEAST & & & & \\
Year of the last childbirth: & & & & \\
$\geq 1990$ and $\leq 2000$ & 1.29 & $.70-2.39$ & 1.25 & $.54-2.85$ \\
$>2000$ and $\leq 2010$ & 1.21 & $.68-2.18$ & 1.41 & $.66-3.05$ \\
$>2010$ & 1.20 & $.63-2.29$ & 1.62 & $.70-3.76$ \\
SOUTH & & & & \\
Year of the last childbirth: & & & & \\
$\geq 1990$ and $\leq 2000$ & .74 & $.36-1.50$ & 2.41 & $.82-7.05$ \\
$>2000$ and $\leq 2010$ & 1.30 & $.63-2.71$ & 2.84 & $1.03-7.80^{*}$ \\
$>2010$ & 1.55 & $.71-3.36$ & 5.75 & $2.00-16.53^{*}$ \\
$\quad$ MIDWEST & & & & \\
\hline Year of the last childbirth: & & & & \\
$\geq 1990$ and $\leq 2000$ & .68 & $.38-1.22$ & .83 & $.35-1.27$ \\
$>2000$ and $\leq 2010$ & .84 & $.46-1.50$ & .95 & $.42-2.13$ \\
$>2010$ & .65 & $.33-1.26$ & 1.17 & $.50-2.76$ \\
\hline
\end{tabular}

Note: $\mathrm{OR}=$ Odds Ratio, $\mathrm{Cl}=$ Confidence interval, ${ }^{\star}$ Statistical significance.

As a peculiarity, the Northeast region demonstrated the fact that, regardless of the level of education (lower level of education OR: 1.75 and CI95:1.07-2.86; higher level of education: OR: 2.42 e CI95:1.15 - 5.12), there was such an increase in C-sections.

Another important data obtained was that the Brazilian women who have health insurance, have 3 times (CI95: 1.69-3.30) more chances of having a C-section. Moreover, those who have good selfreported health, have 84\% (CI95: 1.27 - 2.65) chance of choosing this type of delivery. Still, the chance of undergoing a C-section increased in women with a hypertension diagnosis (2.77 times, CI95: 1.58 4.85), chronic back problem (2 times, CI95:1.01 4.05). Similarly, women of older age at first pregnancy, increase the chances of having a C-section (2 times more likely, CI95: 1.20-3.35), over the years.

\section{Discussion}

Even though public policies, focused on women's health, have been created to strengthen and further expand the care of such women, in addition to encourage them to give birth as humane and natural as possible, C-section rates have increased, as observed in this study. 
According to Patah and Malik [1], in almost all countries worldwide, $\mathrm{C}$-sections are increasingly more frequent. In Brazil, the proportion of C-sections is over $50 \%$ as per study by Rattner and Moura [14]. This scenario can be justified both by social, demographic, cultural and economic factors of pregnant women, and mother's choice for type of delivery and factors related to the care model developed in these countries, involving aspects of medical work and the work of other professionals, medical preferences and economic interests of the parties in this process. These findings tend to corroborate with our study, which showed a prevalence of $53.03 \%$ of $\mathrm{C}$-sections in Brazil. This value increases according to time and factors such as level of education, presence of morbidities and older age of mother at first pregnancy.

Social, demographic, cultural and economic factors, may have influenced the results of this study, since there are regional differences between $\mathrm{C}$-section prevalence. In the South, Southeast and Midwest regions, prevalence were higher and, according to Jesus et al. [12], it's due to the fact that they are urban regions with richer States, with larger numbers of inhabitants and births and more technologies, while the North and Northeast are more rural and poorer States.

These differences between Brazilian regions are striking and, over the years, continue to interfere in this $\mathrm{C}$-section prevalence. This study observed an increasing probability of C-sections in the Northeast and in the South, relating to the temporal variable. This finding refutes, in part, the findings of Rattner and Moura [14], showing that the Midwest region presented higher probability of C-sections and that the proportion of C-sections was lower in the North (42.8\%). Diniz et al. [15] corroborates with our study, stating that, from 2000 to 2010 , the South region was one of the regions that had the highest C-section rate and an increase in the proportion of preterm births in the country (from $6.7 \%$ to $7.1 \%$ ), along with the Southeast region. These results raise questions regarding the causal factors of such increase in regions as distinct as the Northeast and the South of the country. The South region, according to studies by Silva et al. [16] and Monguilhott et al. [17], presents an expansion of the private sphere, to the detriment of the public sphere, in health care, and most women do not have access to the best care practices and may undergo several unnecessary interventions. Private health shows high $\mathrm{C}$-section rates, suggesting to be one of the reasons for this increase over the years.
The Northeast region, according to study by Silva et al. [16], shows disparities in the efficiency of public spending and receive less public resources for health care compared to the Southeast, South and Midwest regions, as well as presenting lower health insurance coverage rates [1], fewer prenatal consultations by pregnant women, with inadequate prenatal care in less favored areas [18]. Therefore, these facts may lead to greater risks and/or maternal-infant complications during pregnancy due to the lack of adequate follow-up, resulting in the indication of $\mathrm{C}$-sections to avoid more serious risks for mother and baby.

Studies [19 - 21] show that the most notable discrepancies observed in C-section rates are in the public and private sectors, with the private sector being significantly higher (80 - 90\%) than the public system (35 - 45\%). Thus, it confirms the data from our study, which found a chance of an increase in C-section rate for women who have private health insurance, either by their own decision or by medical convenience.

Linked to these discussions on the increase in the prevalence of C-sections in Brazil, we also have the fact that the training of health professionals can affect this rate. The doctor-pregnant woman relationship is essentially important at this stage of a woman's life, as well as at the time of delivery. Busanello et al. [22] showed that, despite the Ministry of Health's investment in the implementation of programs for the humanization of care in health services, the training of professionals is one of the least considered areas in the formulation of health policies. Therefore, it is necessary to also implement more educational policies, aimed at professionals working in obstetrics, as well as prioritize investments in Continuing Education, incorporating issues of humanization of childbirth, respect for parturient decisions, interdisciplinary actions, interpersonal relationships, welcoming of parturient and companion, the importance of the companion, incentive to vaginal delivery.

Madeiro, Rufino and Santos [23] corroborate with this thought, defining that the increasing proportion of C-sections points to the need for intervention with a focus on health professionals, women, and the organization and structure of health services. Furthermore, measures such as continuing medical education, quality prenatal consultations and access to good practices during childbirth care may contribute to reducing the proportion of unnecessary C-sections. Diniz et al. [15] point the access to effective and safe maternal health care and 
consider it something extremely important and that can save lives and foster health, while unregulated access to unnecessary and potentially harmful interventions can lead to adverse outcomes.

Concerning the maternal level of education and its relation in C-section rates, this variable was verified as a probable factor that increases the chance of women having C-sections, where, as the level of education increases, there is a greater chance of women to have C-sections. Similar results were found by Rattner and Moura [14], which showed a proportion of C-sections being lower among women with no schooling (25.2\%) and among single women (42.0\%), tending to increase as the level of education improves, and by Faisal-Cury et al. [24], who in one of their analyzes showed that $\mathrm{C}$-sections were associated with higher per capita family income, higher level of education, lower household crowding, pregnancy planning, white skin color, having a partner and older maternal age.

Anjos and Boing [18] analyzed that the level of education was a factor significantly associated with the practice of an increased number of prenatal consultations (seven or more). Similarly, Joshi et al. [25], in a study carried out in Nepal verified that as the level of education of pregnant women increased, their chances of having four or more prenatal consultations also increased, being seven times higher when compared to the extreme groups of schooling. Previous studies $[26,27]$ have already described that mothers with higher levels of education are able to better understand the information they are given, as well as the actions occurring around them, and are better capable of seeking, processing and putting into practice the knowledge they have access to.

Hence, we infer that women with higher levels of education are more autonomous, they solve their doubts, tend to be more careful about signs of complications during pregnancy, better understand the need of time between births and tend to adopt healthy eating habits in order to avoid risks for themselves and the baby. Therefore, we observe that the level of education can influence the attitude of the woman, regarding the information they receive by the health services, as well as the choice of $\mathrm{C}$-section, as a way of delivery. A recent qualitative study by Arik [28] shows that C-sections have emerged in women as a method of avoiding pain and reported unpredictability of vaginal delivery, and includes institutional, organizational and cultural reasons for the preference women have for surgical delivery. On the other hand, the low level of education, according to Aquino et al. [29], causes disinformation, being a constraint of less interest for health care or greater difficulty in accessing health services. And so, this fact can lead to obstetric risks and, consequently, to $\mathrm{C}$-section being carried out. These two extremes of schooling were found as a result in our study of the increasing C-section rate over the years, particularly for the Northeast region of the country.

Considering the maternal older age factor during gestation, our results show that the age of the mother, in the first pregnancy, interfered in the increase of the $\mathrm{C}$-section rate. This finding corroborates with the study by Knupp, Melo and Oliveira [30], revealing that the increase in age is directly proportional to C-section rates, that is, the older the mother, the higher the rate observed. This fact generally leads to a greater chance of having more prenatal consultations (seven or more), due to the high prevalence of maternal and fetal complications. Thus, as these factors are indicative of C-sections, older women tend to choose this type of delivery.

\section{Conclusion}

Brazil continues to have high C-section rates, with more than half of newborns delivered by surgical procedure. Our study showed that the prevalence is higher in the Southeast, South and Midwest regions, however, in the analysis over the years, the Northeast and South regions presented a more significant chance of increasing these $\mathrm{C}$-section rates.

The variables analyzed, such as: time, level of education, advanced maternal age in the first pregnancy, the fact of having a private health insurance, added to the peculiarities observed in the regions, such as the diversity of cultures, socioeconomic conditions, access to health services, quality of care, among other differences in the country, interfere in the increase of the chance of having $\mathrm{C}$-sections in Brazil.

Considering this scenario, it is important to plan and implement public policies that can contemplate such regional differences and those factors that are associated with C-sections. It is also important to emphasize the inclusion of educational actions for health professionals working in the obstetric area, in order to improve welcoming skills, maternal-infant health care and reduce the number of $\mathrm{C}$-sections unnecessarily performed. 
Among the limitations of this study, we emphasize that ecological associations do not mean that there is a causal relationship; however, the results obtained in this study are relevant from the perspective of the prevalence of the general situation in Brazil. Moreover, it was not possible to determine whether the $\mathrm{C}$-sections presented a real indication for each woman in the sample and for each of their deliveries, since the questionnaire applied did not contemplate these aspects. Therefore, for future studies, we suggest such investigation and addition of data to the PNS instrument, as well as data for assessment of the quality of prenatal and birth care, in addition to other variables associated to childbirth, such as mother-baby bond, woman's mental health, pediatric outcomes, which may also interfere in cesarean section prevalence.

\section{References}

1. Patah LEM, Malik AM. Modelos de assistência ao parto e taxa de cesárea em diferentes países. Rev Saude Publica. 2011;45(1):185-94.

2. Villar J, Valladares E, Wojdyla D, Zavaleta N, Carroli G, Velazco A, et al. Caesarean delivery rates and pregnancy outcomes: the 2005 WHO global survey on maternal and perinatal health in Latin America. Lancet. 2006;367(9525):1819-29.

3. Mylonas I, Friese K. Indications for and risks of elective cesarean section. Dtsch Arztebl Int. 2015;112(29-30):489-95.

4. OMS (Organização Mundial da Saúde). Declaração da OMS sobre taxas de cesáreas. Genebra: WHO; 2015.

5. Ye J, Betrán AP, Vela MG, Souza JP, Zhang J. Searching for the optimal rate of medically necessary cesarean delivery. Birth. 2014;41(3):237-44.

6. Belizán JM, Althabe F, Cafferata ML. Health Consequences of the increasing cesarean section rates. Epidemiology. 2007;18(4):485-6.

7. Keag OE, Norman JE, Stock SJ. Long-term risks and benefits associated with cesarean delivery for mother, baby, and subsequent pregnancies: Systematic review and meta-analysis. PLoS Med. 2018;15(1):e1002494.
8. Rocha RS, Silva MGC. Assistência pré-natal na rede básica de Fortaleza-CE: uma avaliação da estrutura, do processo e do resultado. Rev Bras Promoc Saude. 2012;25(3):344-55.

9. Dias MAB, Domingues RMSM, Schilithz AOC, NakamuraPereira M, Leal MC. Factors associated with cesarean delivery during labor in primiparous women assisted in the Brazilian Public Health System: data from a National Survey. Reprod Health. 2016;13(Suppl 3):114.

10. Medeiros PF, Guareschi NMF. Políticas públicas de saúde da mulher: a integralidade em questão. Rev Estud Fem. 2009;17(1):31-48.

11. Brasil. Ministério da Saúde. Política nacional de atenção integral à saúde da mulher: princípios e diretrizes. Brasília: Ministério da Saúde; 2004.

12. Jesus GR, Jesus NR, Peixoto-Filho FM, Lobato G. Caesarean section rates in Brazil: what is involved? BJOG. 2015;122(5):606-9.

13. Souza-Junior PRB, Freitas MPS, Antonaci GA, Szwarcwald CL. Desenho da amostra da Pesquisa Nacional de Saúde 2013. Epidemiol Serv Saude. 2015;24(2):207-16.

14. Rattner D, Moura EC. Nascimentos no Brasil: associação do tipo de parto com variáveis temporais e sociodemográficas. Rev Bras Saude Matern Infant. 2016;16(1):39-47.

15. Diniz CSG, Batista LE, Kalckmann S, Schlithz AOC, Queiroz MR, Carvalho PCA. Desigualdades sociodemográficas e na assistência à maternidade entre puérperas no Sudeste do Brasil segundo cor da pele: dados do inquérito nacional Nascer no Brasil (2011-2012). Saude Soc. 2016;25(3):561-72.

16. Silva ML, Pinto NGM, Cornonel DA, Silva RA. Análise da eficiência dos gastos públicos no Sistema Único de Saúde (SUS). Rev Unifamma. 2016;15(2):83-105.

17. Monguilhott JJC, Brüggemann OM, Freitas PF, d'Orsi E. Nascer no Brasil: the presence of a companion favors the use of best practices in delivery care in the South region of Brazil. Rev Saude Publica. 2018;52:1.

18. Anjos JC, Boing AF. Diferenças regionais e fatores associados ao número de consultas de pré-natal no Brasil: análise do Sistema de Informações sobre Nascidos Vivos em 2013. Rev Bras Epidemiol. 2016;19(4):835-50. 
19. Victora CG, Aquino EML, Leal MC, Monteiro CA, Barros FC, Szwarcwald CL. Maternal and child health in Brazil: progress and challenges. Lancet 2011;377(9780):1863-76.

20. Domingues RMSM, Dias MAB, Nakamura-Pereira $M$, Torres JA, d'Orsi E, Pereira APE, et al. Process of decisionmaking regarding the mode of births in Brazil: from the initial preference of women to the final mode of birth. Cad Saude Publica. 2014;30(Suppl 1):S1-16.

21. Oliveira RR, Melo EC, Novaes ES, Ferracioli PLRV, Mathias TAF. Fatores associados ao parto cesárea nos sistemas público e privado de atenção à saúde. Rev Esc Enferm USP. 2016;50(5):734-41.

22. Busanello J, Kerber NPC, Fernandes GFM, Zacarias CC, Cappellaro J, Silva ME. Humanização do parto e a formação dos profissionais da saúde. Cienc Cuid Saude. 2011;10(1):169-75.

23. Madeiro A, Rufino AC, Santos AO. Partos cesáreos no Piauí: tendência e fatores associados no período 20002011. Epidemiol Serv Saude. 2017;26(1):81-90.

24. Faisal-Cury A, Menezes PR, Quayle J, Santiago K, Matijasevich A. The relationship between indicators of socioeconomic status and cesarean section in public hospitals. Rev Saude Publica. 2017;51:14.

25. Joshi C, Torvaldsen S, Hodgson R, Hayen A. Factors associated with the use and quality of antenatal care in Nepal: a population-based study using the demographic and health survey data. BMC Pregnancy Childbirth 2014;14: 94 .
26. Haidar FH, Oliveira UF, Nascimento LFC. Escolaridade materna: correlação com os indicadores obstétricos. Cad Saude Publica. 2001;17(4):1025-9.

27. Shen C, Williamson JB. Maternal mortality, women's status, and economic dependency in less developed countries: a cross-national analysis. Soc Sci Med. 1999;49(2):197-214.

28. Arik RM. Decisão pelo tipo de parto: estratégia educativa para a promoção do parto vaginal [master's thesis]. Botucatu: Universidade Estadual Paulista; 2017.

29. Aquino TA, Guimarães MJB, Sarinho SW, Ferreira LOC. Fatores de risco para a mortalidade perinatal no Recife, Pernambuco, Brasil, 2003. Cad Saude Publica. 2007;23(12):2853-61.

30. Knupp VMAO, Melo ECP, Oliveira RB. Distribuição do parto vaginal e da cesariana no município do Rio de Janeiro no período de 2001 a 2004. Esc Anna Nery. 2008;12(1):39-44.
Received in 02/01/2018

Recebido em 01/02/2018

Approved in 02/26/2018

Aprovado em 26/02/2018 